\title{
EFFECT OF STOP-HOLE-INDUCED MATERIAL REMOVAL ON THE FATIGUE PROPERTIES OF CRACKED DT4C STEEL
}

\author{
VPLIV ODSTRANITVE MATERIALA ZARADI IZDELAVE \\ IZVRTINE ZA UPOČASNITEV NAPREDOVANJA UTRUJENOSTNE \\ RAZPOKE NA UTRUJANJE JEKLA DT4C
}

\author{
Chunguo Zhang1,*, Rongwei Liu², Qiankun Liü ${ }^{3}$, Cuiping Ren ${ }^{4}$ \\ 1,2,3,4Key Laboratory of Road Construction Technology and Equipment, MOE, Chang'an University, Xi'an 710064, China \\ ${ }^{2}$ Center of Industrial Technology, Chengde Petroleum College, Chengde 067000, China
}

Prejem rokopisa - received: 2019-01-25; sprejem za objavo - accepted for publication: 2019-02-14

doi:10.17222/mit.2019.022

\begin{abstract}
There is a lack of a quantitative study on the appropriate value of material removal $L_{\mathrm{r}}$ from the crack-tip front induced by drilling a stop-hole. The effect of $L_{\mathrm{r}}$ variation on the fatigue life and post-initiation fatigue crack growth rate $(\mathrm{d} a / \mathrm{d} N)$ of a cracked specimen was studied for two different stop-hole geometries (circle and ellipse). Three different values of $L_{\mathrm{r}}=0.3,0.6$ and $0.9 \mathrm{~mm}$ were selected for the parametric study by changing the location of the stop-hole center in relation to the initial fatigue crack-tip. The results show that $L_{\mathrm{r}}=0.6 \mathrm{~mm}$ results in the longest fatigue life and lowest post-initiation da/d $N$ for all the specimens repaired by either circular or elliptical stop-holes. In addition, the fatigue-life extension and post-initiation da/d $N$ reduction resulted from the elliptical stop-hole are significantly more than those of the circular stop-hole for the same $L_{\mathrm{r}}$.

Keywords: stop hole, material removal, fatigue crack growth, fatigue life extension, DT4C steel
\end{abstract}

Do sedaj je bilo izvedenih zelo malo kvantitativnih študij ovrednotenja vpliva odstranitve materiala $L_{\mathrm{r}} \mathrm{Z}$ vrha konice utrujenostne razpoke, ki nastane $\mathrm{z}$ vrtanjem izvrtine za zaustavitev (upočasnitev) napredovanja razpoke med utrujanjem materiala Avtorji opisujejo študijo vpliva variiranja $L_{\mathrm{r}}$ na trajno dinamično trdnost oz. dobo trajanja in hitrost rasti utrujenostne razpoke $(\mathrm{d} a / \mathrm{d} N)$ E-CT preizkušancev s predhodno izdelanimi zarezami, utrujenostnimi razpokami in izvrtinami dveh različnih geometrij (krožno in eliptično). Avtorji so izbrali tri različne vrednosti $L_{\mathrm{r}}(0,3 \mathrm{~mm}, 0,6 \mathrm{~mm}$ in $0,9 \mathrm{~mm})$ za parametrično študijo. Pri tem so spreminjali položaj sredine izvrtine $\mathrm{v}$ odvisnosti od lege konice utrujenostne razpoke. Rezultati so pokazali, da imajo pri $L_{\mathrm{r}}=$ $0,6 \mathrm{~mm}$ vsi izdelani preizkušanci iz izbranega jekla najdaljšo dobo trajanja in najnižjo hitrost napredovanja razpoke da/d $N$, ne glede na geometrijo izvrtine (krožno ali eliptično). Nadalje so ugotovili, da je podaljšanje dobe trajanja in zmanjšanje hitrosti napredovanja razpoke $\mathrm{d} a / \mathrm{d} N$ pri eliptičnih izvrtinah znatno večje kot pri krožnih izvrtinah z enakim $L_{\mathrm{r}}$.

Ključne besede: izvrtine za upočasnitev napredovanja utrujenostne razpoke, odstranitev materiala, rast utrujenostne razpoke, podaljšanje dobe trajanja, DT4C jeklo

\section{INTRODUCTION}

Fatigue cracks are often generated in metallic structural components during their service lives, and propagate to final failure or fracture. ${ }^{1}$ The investigation of crack-growth retardation is a significant subject for increasing the remaining lives of cracked structural components. ${ }^{2}$ There are a number of methodologies of delaying or arresting crack growth to extend the fatigue lives of cracked components, such as welding repair, ${ }^{3,4}$ tensile overload(s), ${ }^{5-7}$ shot peening, ${ }^{8-12}$ indentation, ${ }^{13,14}$ and deposition. ${ }^{15}$ Beyond that, drilling a round hole in the vicinity of fatigue crack-tip, often named the stophole method, is one of the most effective and the easiest crack-growth arresting or retardation techniques for cracked components, ${ }^{16,17}$ which is more effective than infiltration and safer than applying an overload. ${ }^{18}$

To avoid any detrimental influence and/or to increase the potential beneficial influence resulted from drilling stop hole(s), a number of studies have been carried out to

*Corresponding author's e-mail:

zcguo2008@163.com assess the effects of stop-hole geometry, size and configuration on fatigue properties and remaining lives of cracked metals. According to Song et al., ${ }^{19}$ a larger hole diameter can give rise to a longer crack initiation and total fatigue lives as the stop-hole diameter ranges from $2 \mathrm{~mm}$ to $3 \mathrm{~mm}$. Cold expansion induced by inserting pins into stop-holes can further increase the fatigue initiation life from the hole-edge due to the incorporation of compressive residual stress around the holes. ${ }^{20-22}$ In addition to the wide attentions over the geometry, size and configuration of the stop-hole, Chen ${ }^{23}$ innovatively considers the fatigue-behavior influence of the cracked structural component on the appropriate stop-hole size. Most recently, double stop-hole methodology and its optimized configuration relative to the distance between the two centers of the holes have been demonstrated to be conducive to the further enhancement of the fatigue life extension of the cracked specimens. ${ }^{17,18}$

Drilling a stop-hole at the fatigue crack-tip turns the sharp crack into a blunt notch. This methodology can provide a longer fatigue initiation life from the stop-hole edge at the expense of material loss. As is well known, 
the location of the micro crack-tip can be detected accurately even under dynamic loading conditions. ${ }^{24,25}$ With different emphases to those aforementioned studied on stop-hole methods, the primary objective of the present investigation is to study the effect of material removal $L_{\mathrm{r}}$ from crack-tip front induced by drilling a hole on the fatigue properties of cracked specimens by measurements of the total remaining life, initiation life after drilling the stop-hole, and the post-initiation crack-growth rate behavior. The different $L_{\mathrm{r}}$ values were achieved by changing the position of stop-hole center relative to the original fatigue crack-tip.

\section{EFFECT OF DRILLING A STOP-HOLE ON THE STRESS SINGULARITY AT THE FATIGUE CRACK-TIP}

In almost every structural component, stresses vary from point to point during their service lives, and failure will occur in locations where the stresses are the highest or a singularity. In fact the stress concentration is a dominant factor affecting the mechanical failures of a cracked component, ${ }^{26}$ especially fatigue failure. A stress concentration has two main causes: loading mode and geometry change. The effect of geometric features, e.g., hole, crack and notch, is more severe compared with loading modes such as bending and torsion. The influence of a fatigue crack on the stress contribution is much more severe than that of a hole or a notch.

Drilling a stop-hole in the vicinity of the fatigue crack-tip turns the sharp crack into a blunt round-notch. As illustrated in Figure 1, the stress magnitude is unexpectedly high in the immediate vicinity of a crack tip, and rapidly decreases with the distance from the crack tip along the crack growth path for a cracked specimen. In fact, the stress at the fatigue crack-tip is theoretically infinite or singular because the crack-tip radius is almost zero. If we replaced the sharp crack tip with a stop hole without changing the original crack length, however, the stress magnitude in the near-stop-hole region could be significantly reduce in comparison with that in the origi-

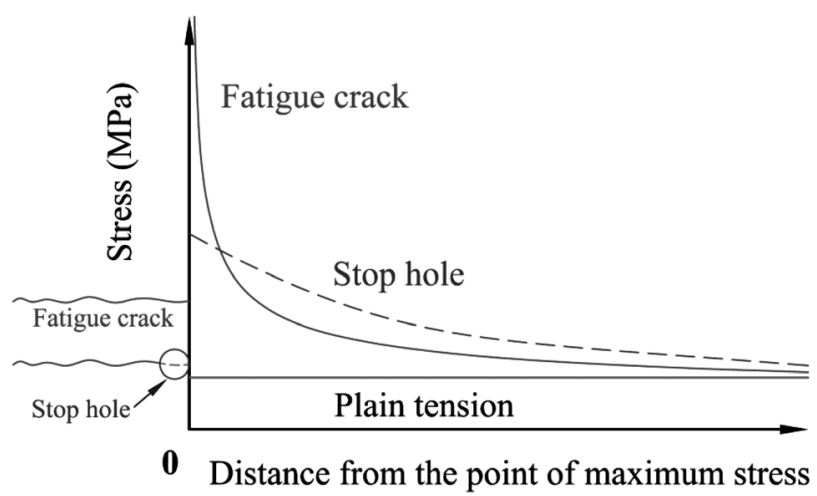

Figure 1: Stress distribution as a function of the distance from the crack tip or the hole edge where is the point of maximum stress, together with that of plain tension, indicating the effect of the geometric features on the stress distribution nal near-crack-tip zone. Thus, drilling a stop-hole at the fatigue crack tip can increase the remaining fatigue life of the cracked components due to the significant decrease of the stress concentration.

\section{EXPERIMENTAL PART}

A commercial DT4C steel widely used for engineering structures subjected to fatigue loading was selected in this study. Its tensile strength is $610 \mathrm{MPa}$, and elongation is $11 \%$. A standard extended-compact tension (E-CT) specimen with a U-notch and with thickness of $10 \mathrm{~mm}$ was adopted for conducting the fatigue crack growth testing to validate the methodology. All the specimens were sliced using wire-electrode cutting from the same plate to avoid any variation of the mechanical properties of the tested specimens.

Firstly, a fatigue pre-crack of $1 \mathrm{~mm}$ from the U-notch root in each E-CT specimen was introduced with a gradually increasing $\Delta K$ (stress intensity factor range) so that the initial total crack length after introducing the fatigue pre-crack was $5.8 \mathrm{~mm}$ from the loading line. Then, the fatigue crack growth tests were performed on the cracked E-CT specimens with and without stop-holes using a servo-hydraulic fatigue-test machine with a capacity of $100 \mathrm{kN}$. For the specimens containing stop-holes, six circular or elliptical stop holes were drilled in each cracked E-CT specimen using wire-electrode cutting when the crack propagated to $a=6.3 \mathrm{~mm}$ from the loading line (or $1.5 \mathrm{~mm}$ from the U-notch root), $8 \mathrm{~mm}$, $9.6 \mathrm{~mm}, 11.2 \mathrm{~mm}, 12.8 \mathrm{~mm}$ and $14.4 \mathrm{~mm}$, respectively. Figure 2 shows the geometry and dimensions of the E-CT specimen, and the geometry and locations of the circular/elliptical stop-holes (e.g., elliptical hole, and material removal $L_{\mathrm{r}}=0.6 \mathrm{~mm}$ ) drilled in each cracked E-CT specimen.

The stop-hole-induced material removal $L_{\mathrm{r}}$ was defined by a measurement of the length from the original fatigue crack-tip to the new circular/elliptical hole edge, as illustrated in Figure 2.

There are a total 14 cracked E-CT specimens with a 1-mm fatigue pre-crack or initial crack $a=5.8 \mathrm{~mm}$ from the loading line: (1) two as-received specimens without drilling any stop-hole; (2) six specimens repaired by circular stop-holes, i.e., two identical specimens for each group of $L_{\mathrm{r}}=0.3 \mathrm{~mm}, L_{\mathrm{r}}=0.6 \mathrm{~mm}$, and $L_{\mathrm{r}}=0.9 \mathrm{~mm}$; (3) six specimens containing elliptical stop-holes, i.e., two identical specimens for each group of $L_{\mathrm{r}}=0.3 \mathrm{~mm}, L_{\mathrm{r}}=$ $0.6 \mathrm{~mm}$, and $L_{\mathrm{r}}=0.9 \mathrm{~mm}$. The radius of circular stop-hole is $2 \mathrm{~mm}$, and the major semi-axis and minor semi-axis of the elliptical stop-hole are respectively $2 \mathrm{~mm}$ and $1 \mathrm{~mm}$ and the direction near the crack is illustrated in Figure 2c. For convenience, the specimen containing six circular stop-holes with $L_{\mathrm{r}}=0.3 \mathrm{~mm}$ is called "C-0.3", and so on, the other five groups of specimens are called C-0.6, C-0.9, E-0.3, E-0.6 and E-0.9, respectively. 


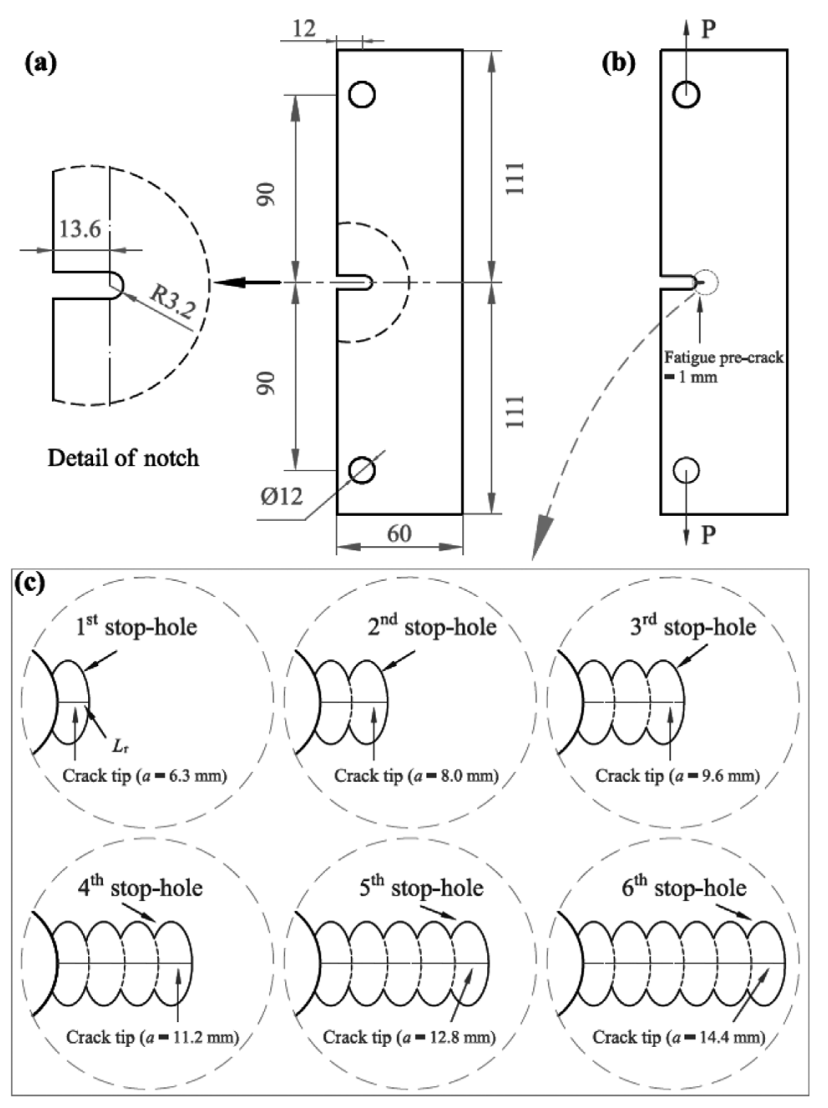

Figure 2: Fatigue samples: a) E-CT specimen (in $\mathrm{mm}$ ), b) specimen containing a fatigue pre-crack of $1 \mathrm{~mm}$, and c) a cracked specimen repaired by six elliptical stop-holes

All the cracked specimens were tested under the same fatigue-loading conditions: constant amplitude axial fatigue loading with haversine waveform at a frequency of $2 \mathrm{~Hz}$, and a load ratio $R \approx 0.02$. The maximum load was set to be $23 \mathrm{kN}$ for all of the specimens. The $a-N$ curves ( $a$ is crack length from the loading line, and $N$ is the number of fatigue cycles) and $\mathrm{d} a / \mathrm{d} N-\Delta K$ curves are plotted in the forthcoming sections, where $\mathrm{d} a / \mathrm{d} N$ is the fatigue crack growth rate and $\Delta K$ is calculated by the following $K$-formula. ${ }^{4}$

$$
\begin{aligned}
& K=\frac{P}{B \sqrt{W}}=\cdot \frac{2+\alpha}{(1-\alpha)^{1.5} \sqrt{(1-d / W)}} . \\
& \left(1.15+0.94 \alpha-2.48 \alpha^{2}+2.95 \alpha^{3}-1.24 \alpha^{4}\right.
\end{aligned}
$$

where $P=$ applied load, $B=$ thickness, $W=$ width of specimen, $\alpha=a /(W-d), a=$ crack length from loading line, $d=$ distance from sample edge to loading line, and $0.1 \leq(a+d) / W<1$.

\section{RESULTS}

The material removal $L_{\mathrm{r}}$ from the fatigue crack-tip front due to drilling a stop hole was considered as a variable parameter for both circular and elliptical stophole methods. For each group of cracked E-CT specimens, two identical samples were measured to check the consistency and reliability of the experimental results. Figure 3 displays the $a-N$ curves of specimens containing stop-holes with different geometries (circle and ellipse) and different material removal $\left(L_{\mathrm{r}}=0.3-0.9 \mathrm{~mm}\right)$, which are to illustrate the effect of $L_{\mathrm{r}}$ variation on the remaining fatigue life of the cracked specimen, and compared with those of the as-received cracked samples. It is clear that the results from two separate tests are very consistent with each other, which therefore provides a reliable estimate to study the $L_{\mathrm{r}}$-variation influences for the two different stop-hole geometries.

As shown in Figure 3, the remaining fatigue lives are significantly increased for all the specimens repaired by either circular or elliptical stop-holes in comparison with those of the as-received samples. It is more important for the specimens containing stop-holes, the number of fatigue cycles first increases then decreases along with the increasing of $L_{\mathrm{r}}$ from $0.3 \mathrm{~mm}$ to $0.9 \mathrm{~mm}$, and that the maximum fatigue life occurs in the case of $L_{\mathrm{r}}=0.3 \mathrm{~mm}$ for both circular and elliptical stop-hole cases. That is the magnitude of the fatigue life extension due to the incorporation of stop holes increases when the $L_{\mathrm{r}}$ value increases from $0.3 \mathrm{~mm}$ to $0.6 \mathrm{~mm}$, but drops instead if $L_{\mathrm{r}}$ further increases from $0.6 \mathrm{~mm}$ to $0.9 \mathrm{~mm}$.

To illustrate the influence of drilling a stop-hole, the $a-N$ curve obtained from an as-received specimen was
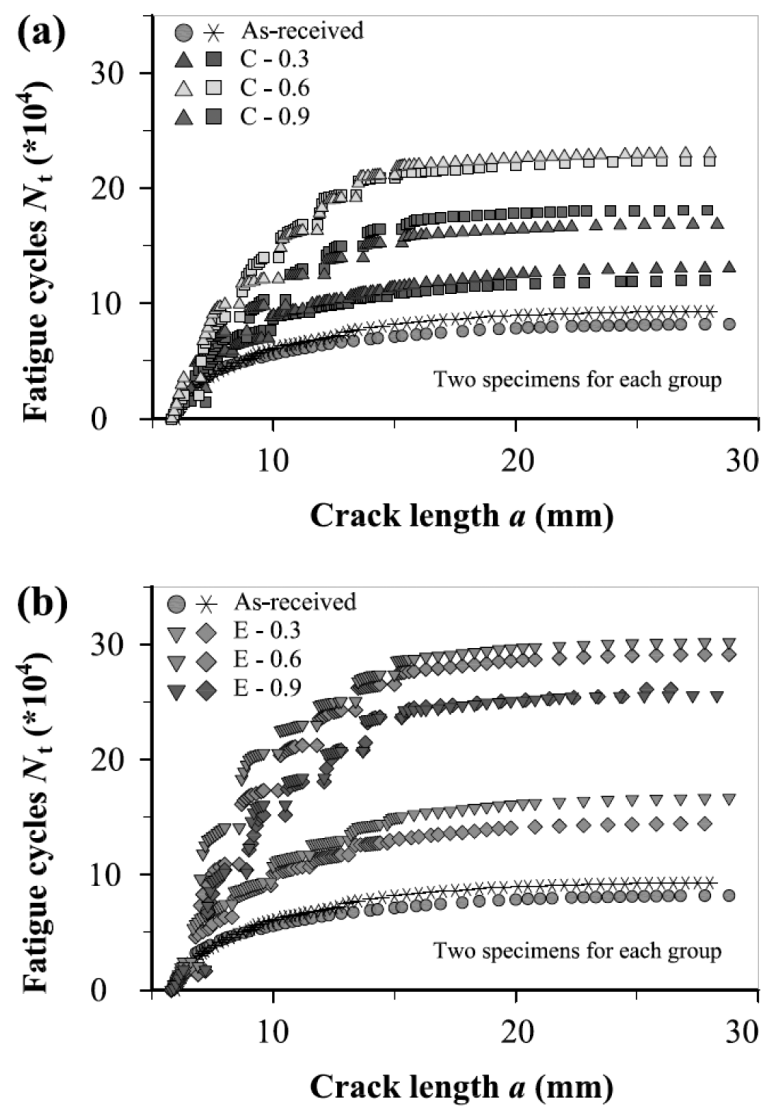

Figure 3: Effect of $L_{\mathrm{r}}$ variation from $0.3 \mathrm{~mm}$ to $0.9 \mathrm{~mm}$ on the remaining fatigue lives of the cracked specimens repaired by: a) circular stop-holes, b) elliptical stop-holes 

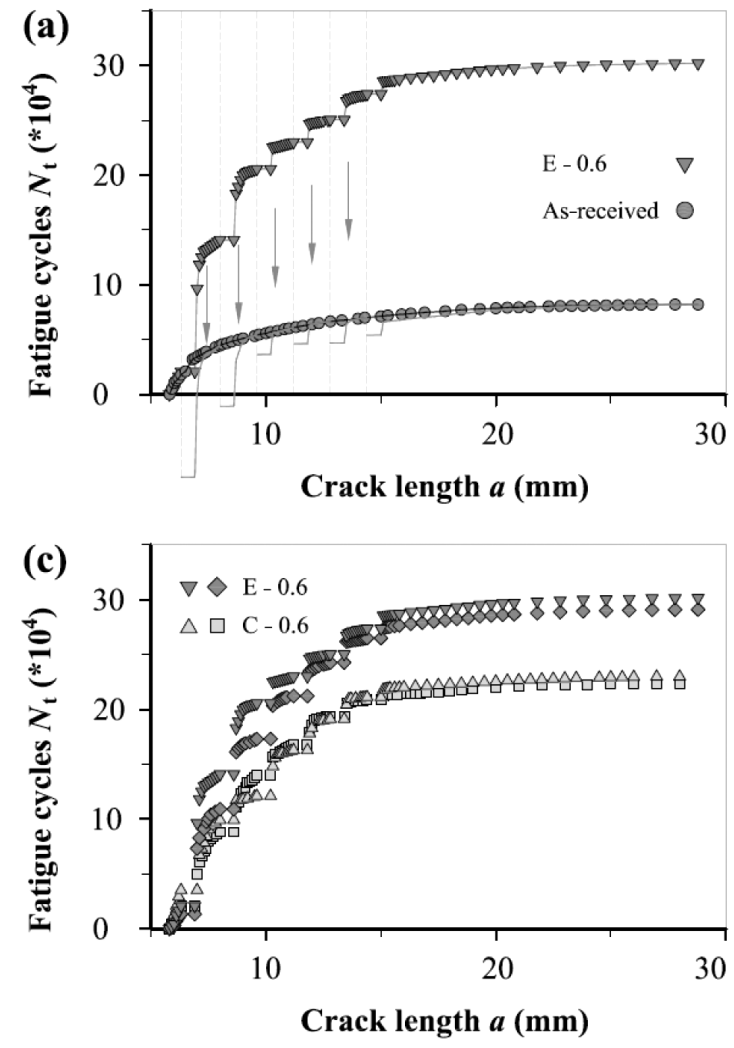
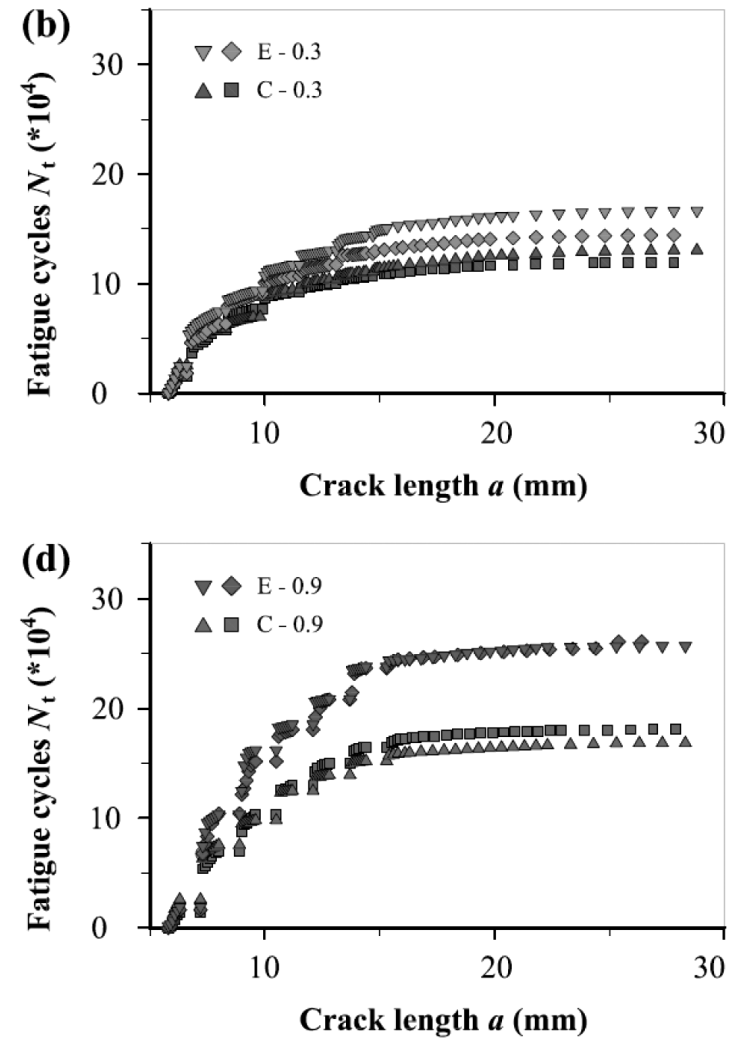

Figure 4: The $a-N$ curves obtained from: a) the specimen repaired by elliptical stop-holes with $L_{\mathrm{r}}=0.6 \mathrm{~mm}$ and the as-received sample, and the specimens containing circular and elliptical stop-holes with: b) $L_{\mathrm{r}}=0.3 \mathrm{~mm}$, c) $L_{\mathrm{r}}=0.6 \mathrm{~mm}$ and d) $L_{\mathrm{r}}=0.9 \mathrm{~mm}$

chosen as the reference property and compared with that of the specimen containing elliptical stop-holes with $L_{\mathrm{r}}=$ $0.6 \mathrm{~mm}$ shown in Figure 4a. Clearly, the slope of the $a-N$ curve after drilling each stop-hole is much higher than the corresponding slope of the as-received specimen for the same crack length, indicating the rate of fatiguecycles rise was significantly increased by drilling a stop hole. To emphasize the hole geometry's influence on the fatigue life, the $a-N$ curves obtained from the specimens with circular and elliptical stop-holes are directly compared in Figure $\mathbf{4 b}$ to $\mathbf{4 d}$ for the cases of $L_{\mathrm{r}}=(0.3$, 0.6 and 0.9$) \mathrm{mm}$, respectively. The remaining fatigue lives of the specimens repaired by the elliptical stopholes are higher than those of the samples with circular stop-holes for the same $L_{\mathrm{r}}$, especial for the cases of $L_{\mathrm{r}}=$ $0.6 \mathrm{~mm}$ and $0.9 \mathrm{~mm}$. Obviously, a smaller curvature or a larger radius around the ellipse vertex is expected to result in a higher fatigue initiation life compared with the case of a circular stop-hole where the curvature is larger.

It should be noted that the $\mathrm{d} a / \mathrm{d} N$ variation after drilling each stop-hole, not recognizable in the $a-N$ curve, is easily identifiable in the Paris curve. The $\mathrm{d} a / \mathrm{d} N$ - $\Delta K$ curves from two separate fatigue-crack-growth tests are shown in Figure 5 for the as-received samples, and in Figure 6 for the specimens containing circular and elliptical stop-holes. Obviously, the experimental results from the two separate tests are very consistent in each group of specimens, which therefore provide reliable results to study the effects of the stop-hole geometry and the $L_{\mathrm{r}}$ value on the subsequent $\mathrm{d} a / \mathrm{d} N$ after drilling each hole in the cracked specimens.

To make a clearer comparison between the asreceived samples and the specimens containing stop-

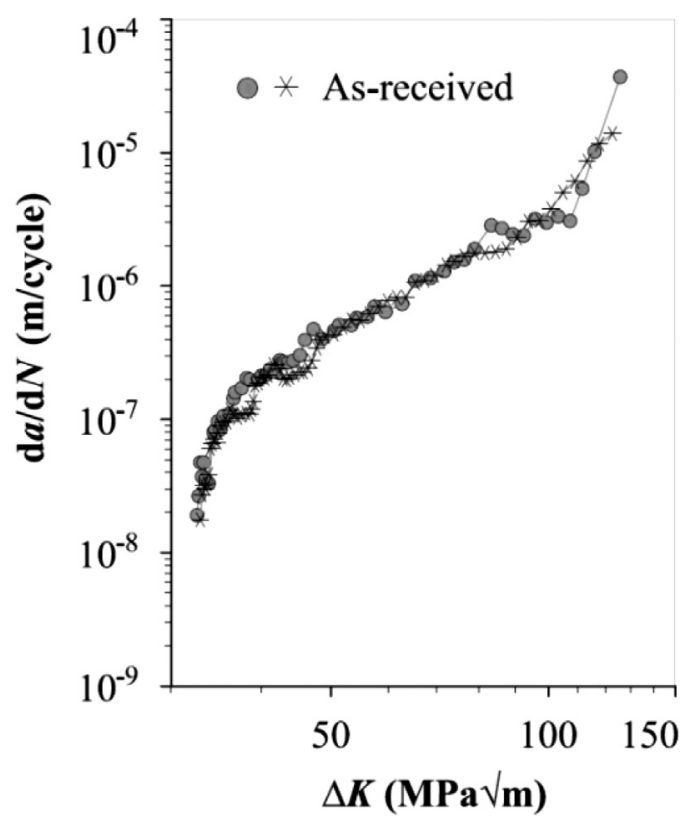

Figure 5: The $\mathrm{d} a / \mathrm{d} N-\Delta K$ curves obtained from the two as-received cracked specimens 
C. ZHANG et al.: EFFECT OF STOP-HOLE-INDUCED MATERIAL REMOVAL ON THE FATIGUE PROPERTIES ...
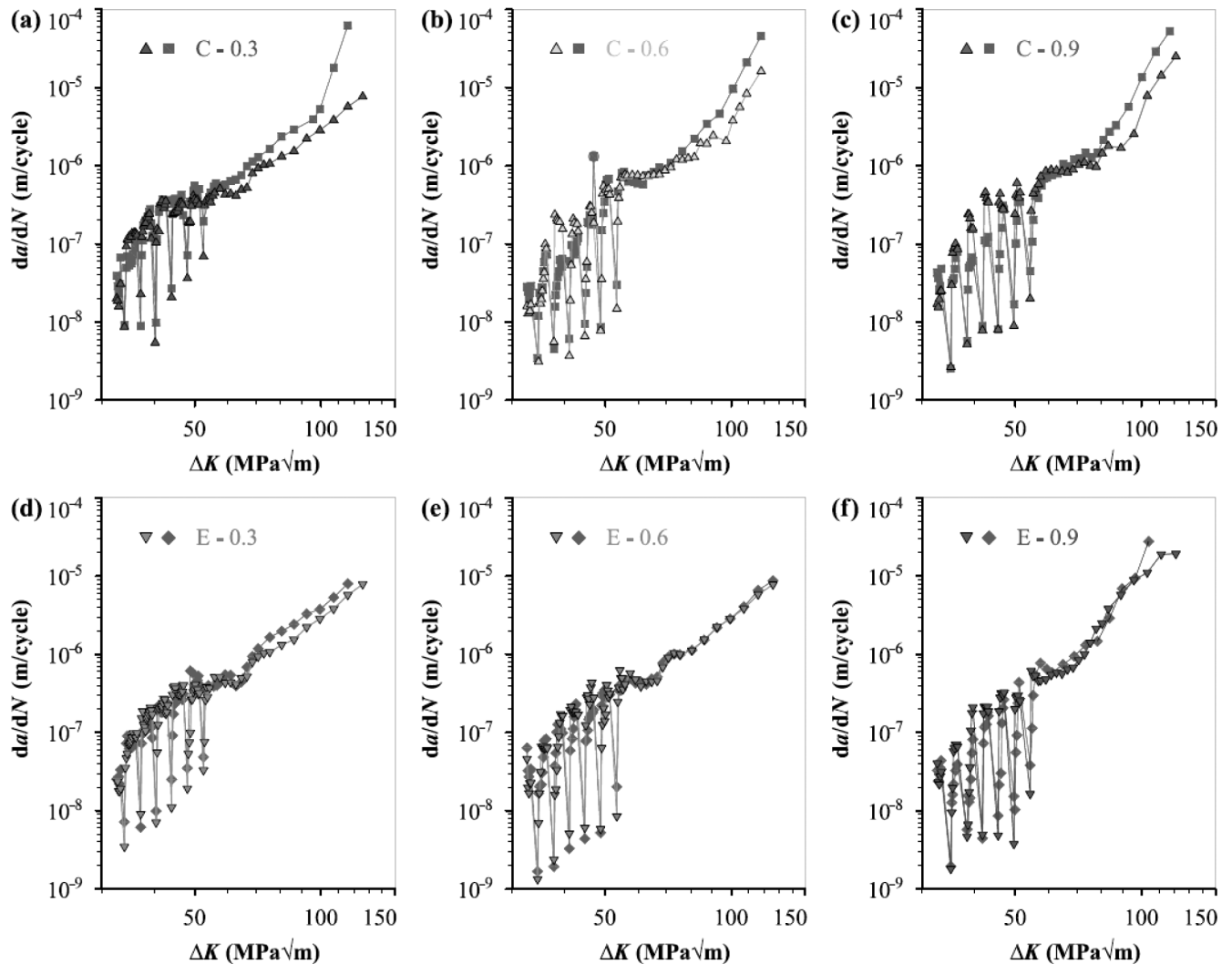

Figure 6: The $\mathrm{d} a / \mathrm{d} N-\Delta K$ curves obtained from two separate tests for each group of specimens repaired by different stop-holes with different $L_{\mathrm{r}}$ : a) $\mathrm{C}-0.3$, b) $\mathrm{C}-0.6$, c) $\mathrm{C}-0.9$, d) $\mathrm{E}-0.3$, e) $\mathrm{E}-0.6$, and f) $\mathrm{E}-0.9$.
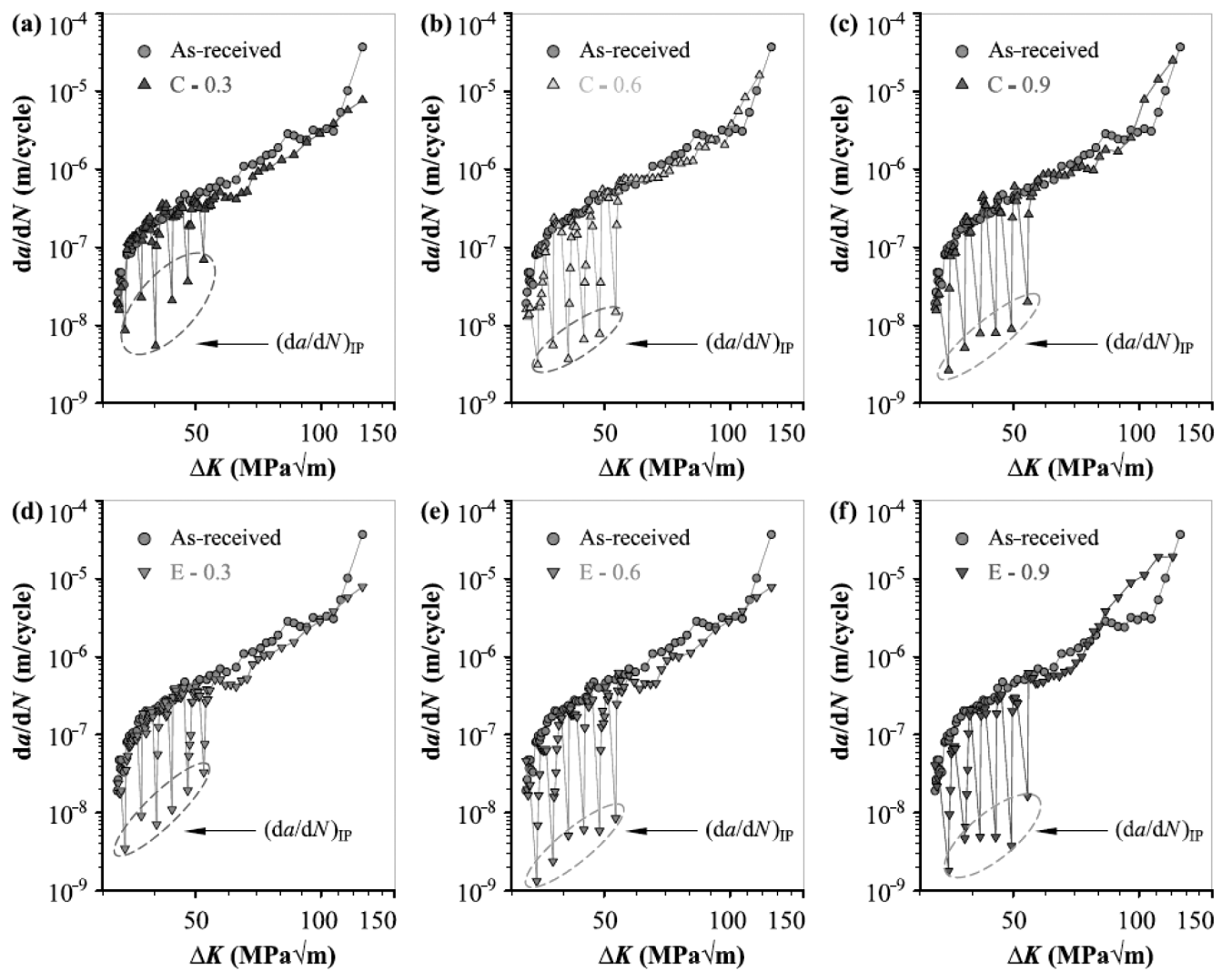

Figure 7: Comparison of $\mathrm{d} a / \mathrm{d} N-\Delta K$ curves between the as-received sample and the specimens repaired by different stop-holes with different $L_{\mathrm{r}}$ : a) $\mathrm{C}-0.3$, b) $\mathrm{C}-0.6$, c) $\mathrm{C}-0.9$, d) $\mathrm{E}-0.3$, e) $\mathrm{E}-0.6$, f) $\mathrm{E}-0.9$ 
holes, only one sample in each group (e.g., the first specimen in Figures 5 and $\mathbf{6}$ ) was selected to study the influence of the $L_{\mathrm{r}}$ variation on the subsequent crackgrowth behavior after drilling the stop-hole. The direct comparisons between the specimens repaired by different stop-hole geometries with different $L_{\mathrm{r}}$ and the as-received specimen are shown in Figure 7 following the $\mathrm{d} a / \mathrm{d} N$ measurements. For the first experimental point of the $\mathrm{d} a / \mathrm{d} N$ measurement after drilling each stop-hole, the "fatigue-crack growth rate" was named as $(\mathrm{d} a / \mathrm{d} N)_{\mathrm{IP}}$. It should be mentioned that the " $N "$ of " $(\mathrm{d} a / \mathrm{d} N)_{\mathrm{IP}}$ " is defined as the summation of fatigue cycles related to the crack initiation from the stop-hole edge and the subsequent crack propagation, and the " $\mathrm{d} a$ " is the increment of the fatigue crack from the hole edge.

It is clear that the value of $(\mathrm{d} a / \mathrm{d} N)_{\mathrm{IP}}$ was obviously reduced with an increasing $L_{\mathrm{r}}$ value from $0.3 \mathrm{~mm}$ to 0.6 $\mathrm{mm}$, but there was no notable difference between $L_{\mathrm{r}}=$ $0.6 \mathrm{~mm}$ and $L_{\mathrm{r}}=0.9 \mathrm{~mm}$ for both the circular and elliptical stop-hole cases. Additionally, the value of $(\mathrm{d} a / \mathrm{d} N)_{\text {IP }}$ obtained from the specimens repaired by the elliptical stop holes is lower than that from the samples containing circular holes for the same $L_{\mathrm{r}}$ value, indicating that an elliptical stop-hole can further decrease the $(\mathrm{d} a / \mathrm{d} N)_{\text {IP }}$ compared with the circular stop-hole. In Figure 7, the first point $(\mathrm{d} a / \mathrm{d} N)_{\mathrm{IP}}$ was followed by a gradual approach to the normal or steady-state crack growth rate, and it became more evident in the cases of $L_{\mathrm{r}}=0.6 \mathrm{~mm}$ in comparison with that of $L_{\mathrm{r}}=0.3 \mathrm{~mm}$ for both the circular and elliptical stop-holes. If the $L_{\mathrm{r}}$ was further increased to 0.9 $\mathrm{mm}$, however, the phenomenon of post-initiation crack-growth retardation was greatly reduced, especially for the specimen with circular stop holes. It has been proved that a similar phenomenon (i.e., post-initiation crack-growth retardation) appears in a cracked CT sample repaired by a single circle stop-hole with various diameters. ${ }^{20}$ The drop of the post-initiation $\mathrm{d} a / \mathrm{d} N$ values is mainly due to the following two reasons: (i) the incorporation of stop-hole built compressive residual stresses in the near-stop-hole region; ${ }^{20}$ (ii) the change of geometry in the near-stop-hole region generates an obvious stress concentration and thus decreases significantly the stress magnitude in the immediate vicinity of the postinitiation crack tip.

\section{DISCUSSION}

For the cracked specimens repaired by stop-holes and the as-received cracked specimens, the fatigue life is defined as the total remaining fatigue lives from the pre-crack of $1 \mathrm{~mm}$ (or initial $a=5.8 \mathrm{~mm}$ ) to the final failure under the same fatigue loading conditions. This is that the fatigue life of a specimen repaired by circular or elliptical stop-holes is the summation of the fatigue cycles related to the crack initiation from each stop-hole edge and subsequent crack propagation. As described earlier, the material removal $L_{\mathrm{r}}$ from the fatigue crack-tip was considered as a variable parameter, which ranges from $0.3 \mathrm{~mm}$ to $0.9 \mathrm{~mm}$ in the study for two different stop-hole geometries.

The fatigue life extension resulting from drilling a stop-hole is due to the sharp crack-tip being replaced by a blunt round-notch, which removed the stress singularity that occurred at the original crack-tip. Figure 8a shows the effect of varying the $L_{\mathrm{r}}$ value on the fatigue-life extension for circular and elliptical stop-hole cases. Obviously, the application of both circular and elliptical stop-holes generates significant improvement in the fatigue life of cracked specimens compared with the as-received cracked specimens. For the two different stop-hole geometries, the cracked specimens with $L_{\mathrm{r}}=$ $0.6 \mathrm{~mm}$ have longer remaining fatigue lives compared with the same stop-hole geometry with $L_{\mathrm{r}}=0.3$. However, the improvement in the life extension began to reduce if $L_{\mathrm{r}}$ was further increased to $0.9 \mathrm{~mm}$. The improvements in the remaining fatigue lives are quantified by: (Average of stop-drilled total fatigue lives - average of as-received total fatigue lives)/average of as-received total fatigue lives. For the average of the fatigue lives, the $L_{\mathrm{r}}=(0.3,0.6$, and 0.9$) \mathrm{mm}$ stop-holes improved the non-stop-drilled total fatigue life by respective $43 \%$, $159 \%$ and $98 \%$ for circular stop-holes, and a respective $78 \%, 239 \%$ and $195 \%$ for the elliptical cases. Furthermore, the difference in the fatigue life improvements coming from circular and elliptical stop-holes for the same $L_{\mathrm{r}}$ value increases gradually when $L_{\mathrm{r}}$ increases from $0.3 \mathrm{~mm}$ to $0.9 \mathrm{~mm}$.

For all the cases in this analyses, the fatigue-life improvement coming from the elliptical stop-hole models are more efficient than that of the circular stop-holes under the same $L_{\mathrm{r}}$ value. After drilling a stop-hole in the vicinity of a crack tip, the fatigue crack emanates along the initial fatigue crack growth path and from the hole edge where the stress reaches its local maximum value. A larger curvature radius of the oval vertex, reducing the stress concentration, is expected to result in a higher fatigue-crack initiation life compared with the case of circular stop-holes where the curvature radius is smaller, thus that will be a significant reason for increasing the total fatigue life of specimens with elliptical stop-holes. This conclusion was evidenced by the experimental results as shown in Figures 8c and 8d, especially for the case of $L_{\mathrm{r}}=0.6 \mathrm{~mm}$. Therefore, from a practical point of view, the elliptical stop-hole with $L_{\mathrm{r}}=$ $0.6 \mathrm{~mm}$ is suggested as an appropriate scheme for the drilling stop-hole methodology.

Figure 9 illustrates of the fatigue initiation life after drilling each stop-hole for different hole geometries and also for different $L_{\mathrm{r}}$ values. It is evident that the fatigue initiation life after each stop-hole gradually decreases from the $1^{\text {st }}$ to the $6^{\text {th }}$ stop-holes for both circular and elliptical cases, which because the applied $\Delta K$ continuously increases with an increase of the crack length under constant amplitude fatigue loading. For both the 

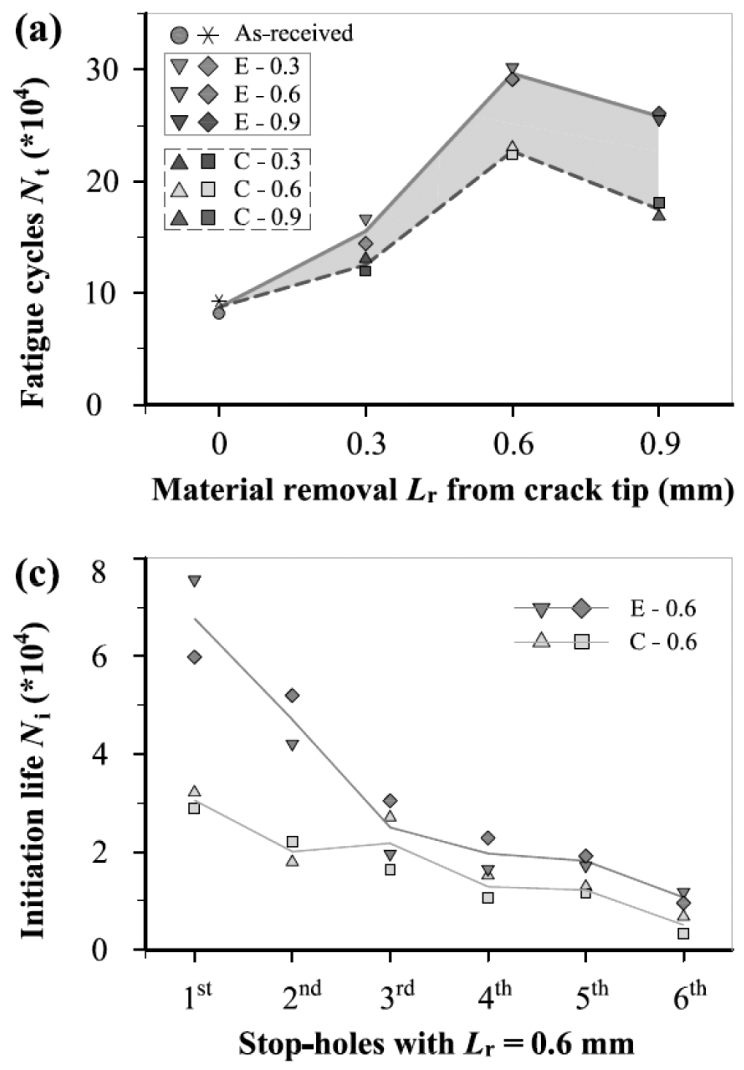
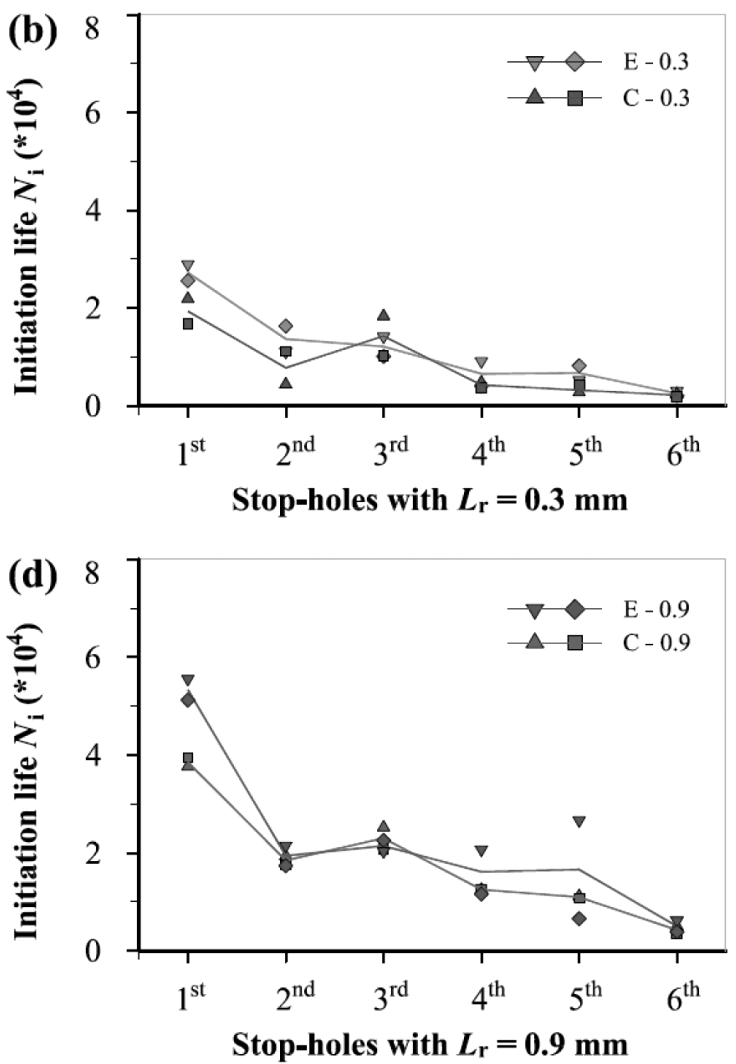

Figure 8: a) Effect of $L_{\mathrm{r}}$ value on the remaining fatigue lives of cracked specimens repaired by different stop-holes $\left(L_{\mathrm{r}}=0\right.$ denotes the as-received specimens), and fatigue-initiation-life comparisons between the circular and elliptical stop-hole cases for: b) $L_{\mathrm{r}}=0.3 \mathrm{~mm}$, c) $L_{\mathrm{r}}=0.6$ $\mathrm{mm}$ and d) $L_{\mathrm{r}}=0.9 \mathrm{~mm}$
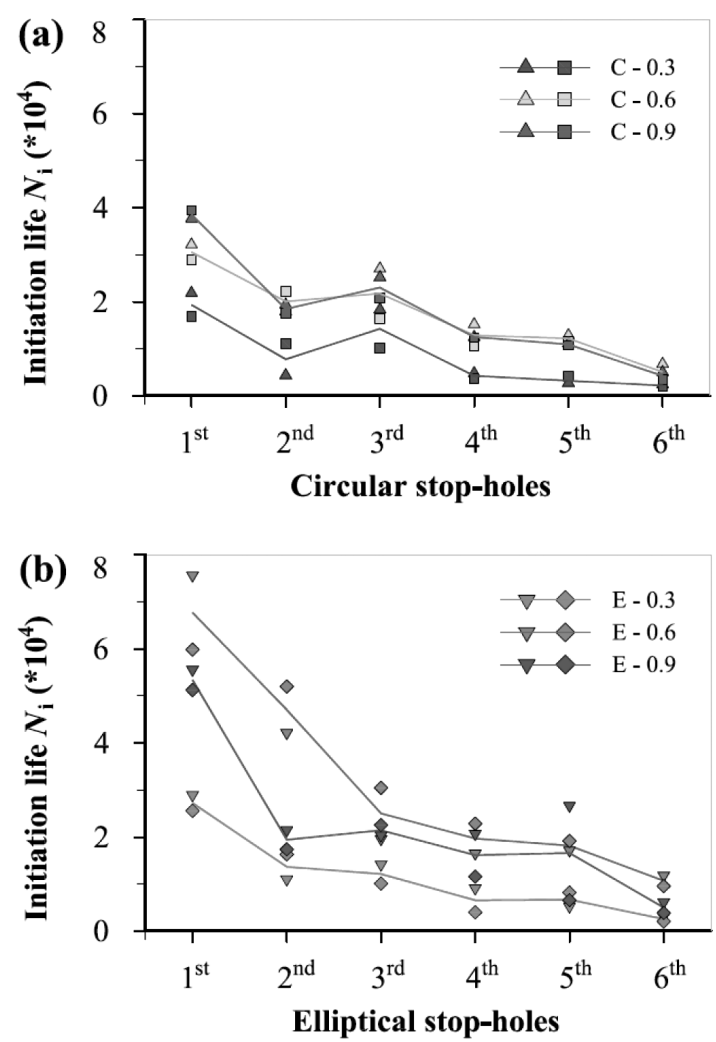

Figure 9: Fatigue initiation lives after drilling each stop hole with different Lr-value: a) circular stop-hole, b) elliptical stop-hole circular and the elliptical stop-hole specimens, fatigue initiation lives from each stop-hole edge increase significantly when $L_{\mathrm{r}}$ increased from $0.3 \mathrm{~mm}$ to $0.6 \mathrm{~mm}$. However, the initiation lives of the circular stop-hole samples are approximately the same for $L_{\mathrm{r}}=0.6 \mathrm{~mm}$ and $0.9 \mathrm{~mm}$ cases, and the elliptical stop-hole specimens with $L_{\mathrm{r}}=$ $0.6 \mathrm{~mm}$ generate higher initiation lives compared with the $L_{\mathrm{r}}=0.9 \mathrm{~mm}$ case. After drilling each stop-hole, although the $L_{\mathrm{r}}=0.9 \mathrm{~mm}$ specimen has slightly higher $\Delta K$ than the $L_{\mathrm{r}}=0.6 \mathrm{~mm}$ during the subsequent fatigue loading, the comparative differences between the $\Delta K$-values of the circular and elliptical stop-hole samples are only in the $0.56-0.90 \mathrm{MPa} \sqrt{\mathrm{m}}(1.59-1.69 \%)$ depending on the crack length. Similar situations also occur in the $L_{\mathrm{r}}=0.3 \mathrm{~mm}$ and $0.6 \mathrm{~mm}$ cases.

During fatigue loading, the non-uniformity of the fatigue crack-tip from the surface to the middle of the cracked specimen along thickness direction should be a significant reason for explaining the influence of the $L_{\mathrm{r}}$ variation on the fatigue life of the cracked specimens repaired by a stop-hole. To put the real crack-growthpattern into perspective, Figure 10 shows the macro-section of a fatigue-fractured E-CT sample. It is conceivable that the observed variation in the crack tip along the thickness direction during the fatigue testing was formed because of the different constraint from the surfaces to the middle of the sample. For ductile materials like steel, 


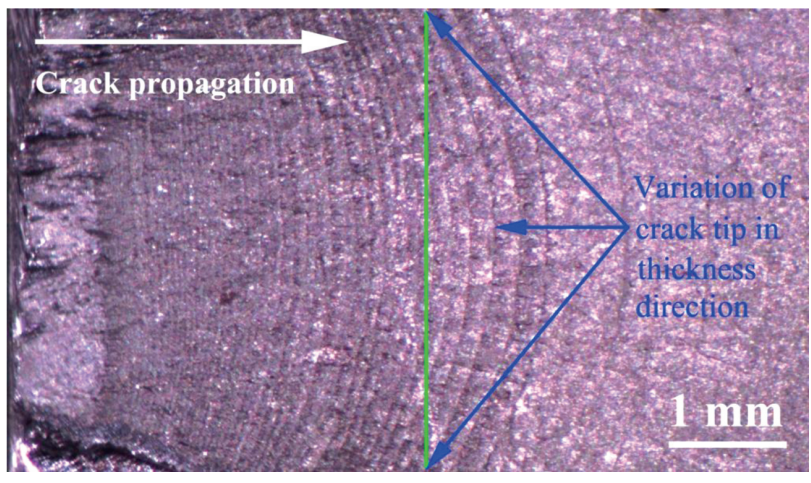

Figure 10: Fracture surface of fatigue E-CT sample showing the variation of the crack tip in the thickness direction

the most advanced and active crack-tip occurs in the middle of sample, and the most underdeveloped and sluggish crack tip is on the surfaces, which is the crack length measured for the $\mathrm{d} a / \mathrm{d} N$ calculation. The maximum difference of the crack tip from the surfaces to the center of the cracked specimen is approximately $0.6 \mathrm{~mm}$. It is a logical explanation that $L_{\mathrm{r}}=0.3 \mathrm{~mm}$ stop-hole only removed the part of crack tip near the two surfaces in which a new crack can easily form, $L_{\mathrm{r}}=0.6 \mathrm{~mm}$ eliminated all the crack tips, and $L_{\mathrm{r}}=0.9 \mathrm{~mm}$ was greater than the maximum difference of crack tip between surfaces and the center of the specimen.

As is well known, stop-hole technique has both beneficial and harmful influences on fatigue-life-extension of a cracked specimen. That is, replacing the fatigue crack-tip with a blunt stop-hole generates a longer fatigue life for cracked specimen due to eliminating the stress singularity at the original crack-tip, but drilling hole-induced material removal from the crack-tip front reduces the length of the fatigue crack propagation, which removes the corresponding fatigue propagation life. A key challenge with the stop-hole method is that it is hard to balance them. To the best of our knowledge, it is the first time that material removal $L_{\mathrm{r}}$ is linked to the fatigue life extension, specified by the total fatigue life, initiation life after drilling each stop-hole and subsequent crack growth rate.

Although the quantification is specific to DT4C steel, the approach developed in this study can be applied to the fatigue life extension of other metals and other types of cracked components. Considering the extensive use of the stop-hole method in engineering industries like airplanes and high-speed rail, the elliptical stop-hole with an appropriate $L_{\mathrm{r}}$ (e.g., $L_{\mathrm{r}}=0.6 \mathrm{~mm}$ for DT4C steel plate with $10 \mathrm{~mm}$ thickness in this study) is recommended as an efficient approach for fatigue life improvement in cracked metallic structural components.

\section{CONCLUSIONS}

The effect of material removal $L_{\mathrm{r}}$ from the crack-tip front on the fatigue properties of cracked E-CT specimens repaired by either circular or elliptical stop-holes was studied by measurements of the crack initiation life and post-initiation $\mathrm{d} a / \mathrm{d} N$ after drilling each stop-hole, and the remaining fatigue life. The major findings can be drawn as follows:

For both circular and elliptical stop-hole methods, drilling a stop-hole with different $L_{\mathrm{r}}$ value ranged from $0.3 \mathrm{~mm}$ to $0.9 \mathrm{~mm}$ could provide a considerable fatigue life extension and a dramatic reduction in the post-initiation $\mathrm{d} a / \mathrm{d} N$ due to the incorporation of compressive residual stresses in the near-stop-hole region and the reduction of the stress magnitude in the immediate vicinity of the post-initiation crack tip.

Due to the non-uniformity of the crack-tip in the sample thickness direction, material removal $L_{\mathrm{r}}$ is a key parameter affecting the fatigue-life extension of a cracked specimen repaired by stop-holes.

The fatigue-life extension of cracked specimens is more efficient for $L_{\mathrm{r}}=0.6 \mathrm{~mm}$ than any other $L_{\mathrm{r}}$ value for the stop-hole method. For average of the fatigue lives in this study, the $L_{\mathrm{r}}=(0.3,0.6$, and 0.9$) \mathrm{mm}$ stop-holes increased the non-stop-drilled remaining fatigue life by a respective $43 \%, 159 \%$ and $98 \%$ for circular stop-holes, and increased by a respective $78 \%, 239 \%$ and $195 \%$ for elliptical stop-holes.

The magnitude of the fatigue-life improvement for the elliptical stop-hole specimens is significantly greater, which resulted from the larger curvature radius of the oval vertex, lowering the stress concentration, than that for the samples containing circular stop-holes with the same $L_{\mathrm{r}}$.

\section{Acknowledgements}

This work was supported by the National Natural Science Foundation of China (No. 11672048 and 51405029), Shaanxi Province (No. 2017KJXX-11 and 2016JQ5020), and Chang'an University (No. 310825153510).

\section{REFERENCES}

\footnotetext{
${ }^{1}$ M. R. Ayatollahi, S. M. J. Razavi, M. Y. Yahya, Mixed mode fatigue crack initiation and growth in a CT specimen repaired by stop hole technique, Eng Fract Mech, 145 (2015), 115-127, doi:10.1016/ j.engfracmech.2015.03.027

${ }^{2}$ Z. Domazet, Comparison of fatigue crack retardation methods, Eng Fail Anal, 3 (1996), 137-147, doi:10.1016/1350-6307(96)00006-4

${ }^{3}$ P. F. Mendez, T. W. Eagar, Penetration and defect formation in highcurrent arc welding, Weld J 82 (2003), 296-306, doi:10.2172/835707

${ }^{4}$ C. G. Zhang, S. van der Vyer, X. Hu, P. Lu, Fatigue crack growth behaviour in weld-repaired high strength low alloy steel, Eng Fract Mech, 78 (2011), 1862-1875, doi:10.1016/j.engfracmech.2011. 03.004
} 
${ }^{5}$ C. G. Zhang, X. Hu, P. Lu, G. P. Zhang, Tensile overload-induced plastic deformation and fatigue behavior in weld-repaired highstrength low-alloy steel, J Mater Process Tech, 213 (2013), 2005-2014

${ }^{6}$ E. Salvati, S. O’Connor, T. Sui, D. Nowell, A. M. Korsunsky, A study of overload effect on fatigue crack propagation using EBSD, FIB-DIC and FEM methods, Eng Fract Mech, 167 (2016), 210-223, doi:10.1016/j.jmatprotec.2013.05.018

${ }^{7}$ X. Zheng, H. Cui, C. C. Engler-Pinto Jr, X. Su, W. Wen, Numerical modeling of fatigue crack propagation based on the theory of critical distances: effects of overloads and underloads, Eng Fract Mech, 218 (2014), 91-102, doi:10.1016/j.engfracmech.2014.07.006

${ }^{8}$ S. Huang, J. Sheng, J. Z. Zhou, J. Z. Lu, X. K. Meng, S. Q. Xu, H. F. Zhang, On the influence of laser peening with different coverage areas on fatigue response and fracture behavior of Ti-6Al-4V alloy, Eng Fract Mech, 147 (2015), 72-82, doi:10.1016/j.engfracmech. 2015.08.026

${ }^{9}$ A. Chahardehi, F. P. Brennan, A. Steuwer, The effect of residual stresses arising from laser shock peening on fatigue crack growth, Eng Fract Mech, 77 (2010), 2033-2039, 10.1016/j.engfracmech. 2010.03.033

${ }^{10}$ S. Huang, J. Z. Zhou, J. Sheng, J. Z. Lu, G. F. Sun, X. K. Meng, L. D. Zuo, H. Y. Ruan, H. S. Chen, Effects of laser energy on fatigue crack growth properties of 6061-T6 aluminum alloy subjected to multiple laser peening, Eng Fract Mech, 99 (2013), 87-100, doi:10.1016/j.engfracmech.2013.01.011

${ }^{11} \mathrm{~S}$. Bagherifard, M. Guagliano, Fatigue behavior of a low-alloy steel with nanostructured surface obtained by severe shot peening, Eng Fract Mech, 81 (2012), 56-68, doi:10.1016/j.engfracmech.2011. 06.011

${ }^{12}$ J. Sakamoto, Y. S. Lee, S. K. Cheong, Effect of surface flaw on fatigue strength of shot-peening medium-carbon steel, Eng Fract Mech, 133 (2015), 99-111, doi:10.1016/j.engfracmech.2014.11.005

${ }^{13}$ W. K. Lim, J. S. Yoo, S. Y. Choi, The effects of concurrent coldexpansion and ring-indentation on the growth of fatigue cracks emanating from circular holes, Eng Fract Mech, 59 (1998), 643-653, doi:10.1016/s0013-7944(97)00125-2

${ }^{14}$ K. Ruzek, J. Pavlas, R. Doubrava, Application of indentation as a retardation mechanism for fatigue crack growth, Int J Fatigue, 37 (2012), 92-99, doi:10.1016/j.ijfatigue.2011.09.012
${ }^{15}$ P. S. Song, B. C. Sheu, H. H. Chou, Deposition of plating metals to improve crack growth life, Int J Fatigue, 23 (2001), 259-270, doi:10.1016/s0142-1123(00)00084-0

${ }^{16}$ H. Wu, A. Imad, N. Benseddiq, J. T. P. Castro, M .A. Meggiolaro, On the prediction of the residual fatigue life of cracked structures repaired by the stop-hole method, Int J Fatigue, 32 (2010), 670-677, doi:10.1016/j.ijfatigue.2009.09.011

${ }^{17}$ S. M. J. Razavi, M. R. Ayatollahi, C. Sommitsch, C. Moser, Retardation of fatigue crack growth in high strength steel S690 using a modified stop-hole technique, Eng Fract Mech, 169 (2017), 226-237, doi:10.1016/j.engfracmech.2016.11.013

${ }^{18}$ M. R. Ayatollahi, S. M. J. Razavi, C. Sommitsch, C. Moser, Fatigue life extension by crack repair using double stop-hole technique, Mater Sci Forum, 879 (2017), 3-8, doi:10.4028/www.scientific.net/ MSF.879.3

${ }^{19}$ C. S. Shin, C. M. Wang, P. S. Song, Fatigue damage repair: a comparison of some possible methods, Int J Fatigue, 18 (1996), 535-546, doi:10.1016/s0142-1123(96)00029-1

${ }^{20}$ P. S. Song, Y. L. Shieh, Stop drilling procedure for fatigue improvement, Int J Fatigue, 26 (2004), 1333-1339, doi:10.1016/j.ijfatigue. 2004.04.009

${ }^{21}$ R. J. Callinan, C. H. Wang, On the fatigue enhancement of interference fitted stop drilled holes, Int J Fatigue, 21 (1999), 865-872, doi:10.1016/S0142-1123(99)00013-4

${ }^{22}$ R. Ghfiri, H. Shi, R. Guo, G. Mesmacque, Effects of expanded and non-expanded hole on the delay of arresting crack propagation for aluminum alloys Mater Sci Eng A, 286 (2000), 244-249, doi:10.1016/s0921-5093(00)00805-4

${ }^{23}$ R. Ghfiri, A. Amrouche, A. Imad, G. Mesmacque, Fatigue life estimation after crack repair in 6005 AT-6 aluminum alloy using the cold expansion hole technique, Fatigue Fract Eng Mater Struct, 23 (2000), 911-916, doi:10.1046/j.1460-2695.2000.00356.x

${ }^{24}$ Z. Qiu et. al., Dynamic visualization of stress/strain distribution and fatigue crack propagation by an organic mechanoresponsive AIE luminogen, Adv Mater (2018), 1803924, doi:10.1002/adma. 201803924

${ }^{25}$ K. C. Jajam, H. V. Tippur, An experimental investigation of dynamic crack growth past a stiff inclusion, Eng Fract Mech, 78 (2011), 1289-1305, doi:10.1016/j.engfracmech.2011.02.005

${ }^{26} \mathrm{D}$. Taylor, The theory of critical distances: A new perspective in fracture mechanics, $1^{\text {st }}$ ed., Oxford, London 2007 